\title{
Gambaran Kasus Demam Berdarah Dengue (DBD) di Provinsi Bali Tahun 2012-2017
}

\author{
Ririh Yudhastuti ${ }^{1}$, Muhammad Farid Dimjati Lusno ${ }^{1^{*}}$ \\ ${ }^{1}$ Fakultas Kesehatan Masyarakat Universitas Airlangga \\ *Coresponding author:faridlusno@fkm.unair.ac.id
}

Info Artikel : Diterima 30 Agustus 2019 ; Disetujui 11 Desember 2019 ; Publikasi 1 April 2020

\begin{abstract}
ABSTRAK
Latar Belakang:Demam Berdarah Dengue (DBD) hingga saat ini masih merupakan masalah kesehatan masyarakat di Indonesia, termasuk pulau Bali. Provinsi bali yang terdiri dari 9 kabupaten/kota adalah daerah endemis DBD, padahal Provinsi Bali adalah destinasi wisata baik lokal maupun mancanegara. Penelitian ini bertujuan untuk memberikan pemaparan berupa gambaran kejadian DBD di Provinsi Bali.

Metode:Penelitian ini merupakan penelitian deskriptif dengan rancang bangun case series. Sumber data pada penelitian ini menggunakan data sekunder yaitu Profil Kesehatan provinsi Bali tahun 2015 hingga 2017, dan data iklim di Provinsi Bali tahun 2015-2017 yang diperoleh dari Badan Pusat Statistik provinsi Bali.

Hasil: Hasil penelitian menunjukkan insiden DBD per 100000 penduduk di Provinsi Bali tahun 2012 hingga tahun 2017 berturut turut 65,5: 174,5: 210,2; 259,1; 483; 105. Puncak insiden tertinggi Demam Berdarah Dengue (DBD) ada pada tahun 2016. Pada tahun 2017 ada 4 kabupaten/kota yang insidennya tinggi seperti kabupaten Badung, kota Denpasar, kabupaten Buleleng dan kabupaten Gianyar. Penyebab meningkatnya insiden DBD adalah banyaknya genangan air sebagai tempat perindukan nyamuk Aedes aegypti saat musim hujan, sehingga populasi nyamuk Aedes aegypti meningkat. Insidens DBD terjadi pada bulan Januari hingga Mei, yang di pengaruhi oleh cuaca lokal, kondisi sosial ekonomi masyarakat, curah hujan, topografi maupun kepadatan, serta mobilitas penduduk.

Simpulan:Insiden DBD dipengaruhi oleh pola musim hujan, di bulan Januari, Februari, Maret, April dan Mei didukung kepadatan dan mobilitas dari penduduk.
\end{abstract}

Kata Kunci: Cuaca; Bali; DBD; Kepadatan dan migrasi penduduk

\section{ABSTRACT}

Title:An Overview of Dengue Haemorrhagic Fever Cases in Bali Island 2012-2017

Background:Dengue Hemorrhagic Fever (DHF) remains a public health problem in Indonesia, including the island of Bali. Bali province consists of 9 regencies / cities is a dengue endemic area, whereas the island of Bali is a tourist destination both locally and internationally. This study aims to provide an overview of the incidence rates (IR) of DHF in the island of Bali.

Methods:This research is a descriptive study with case series design. Data sources in this study use secondary data obtianed from Bali Health Profile 2015 - 2017, and the climate data of Bali Province in 2015-2017 was obtained from the Central Statistics Agency (BPS) of Bali Province.

Results:The results showed the Incidence Rates (IR) of Dengue Haemorrhagic Fever (DHF) in the island of Bali in 2012- 2017 were $65.5 ; 174.5 ; 210.2$; 259.1; 483 and 105.7 respectively. The highest incidence rates (IR) of DHF was notified in 2016. Up to 2017 there were 4 districts that had reported high incidence of DHF, such as Badung Regency, Denpasar City, Buleleng Regency, and Gianyar Regency. Factors contributing to the increasing incidence of DHF in Bali were the existence of water container as the potential breeding places for mosquitos vector of Aedes aegypti, particularly during rainy season. This condition initiated the increased population of Aedes aegypti. The incidence of dengue fever cases intensively occurred during January - May influenced by local weather climate, socio- economic condition, rainfall, topography, as well as population density and mobility 
Conclusion:The incidence ofDHF is significantly associated with weather seasonal patterns whereas the highest DHF incidence rates are found in each year in January, February, March, April and May. The other significant factors are including of rainfall, population density and mobility.

Keywords: local weather; DHF; density and mobility; Bali

\section{PENDAHULUAN}

Demam Berdarah Dengue (DBD) masih menjadi masalah kesehatan masyarakat di Indonesia, pada akhir tahun 2018, wabah Demam Berdarah Dengue (DBD) telah dilaporkan di 34 provinsi dan 514 kabupaten di seluruh Indonesia. DBD telah menjadi beban kesehatan di Indonesia, untuk itu perlu dilakukan penanggulangan, Pemerintah telah menerapkan strategi yang berfokus pada pengendalian populasi vektor melalui aksi pengendalian vektor berbasis masyarakat seperti Pembersihan sarang Nyamuk (PSN) dan $3 \mathrm{M}$ yaitu: menguras, menutup dan mengubur. Program ini masih tetap menjadi andalan dalam membunuh jentik nyamuk, dan meminimalisir terjadinya penyakit yang disebabkan oleh nyamuk.serta pengendalian berbasis bahan kimia seperti fogging ${ }^{1,2}$

Di Indonesia, pada tahun 2016 ,Bali adalah salah satu provinsi dengan kejadian Demam Berdarah Dengue (DBD) tertinggi dengan insiden per penduduk 483. Demam berdarah adalah penyakit demam akut yang disebabkan oleh virus dengue yang ditularkan oleh nyamuk (DENV), yang terdiri dari empat serotipe (DENV 1 hingga 4), yang merupakan anggota keluarga flaviviridae, genus flavirus. ${ }^{1}$ Keempat serotipe DENV telah muncul dari strain silvatic di Asia Tenggara, Keempat strain virus dengue telah ditemukan beredar di pulau $\mathrm{Bali}^{3,4}$, dengan demikian Bali dianggap tempat yang penting untuk penularan DBD. Hal ini sangat penting karena Pulau Bali merupakan daerah destinasi wisata baik turis lokal maupun internasional.

Bali dikenal dengan daerah endemis DBD karena 9 kabupaten/kota setiap tahunnya ada kasus $\mathrm{DBD}^{4,5}$. Belum ada prediksi yang tepat untuk meramal dari kepadatan vektor(terutama Aedesaegypti di lingkungan kabupaten/kota di Pulau Bali.

Penyebaran kejadian Demam Berdarah Dengue (DBD) dipengaruhi oleh faktor geografi, iklim, maupun jumlah penduduk ${ }^{6,7}$,perilaku vektor,dan hubungannya dengan iklim,pengendalian vektor, mobilitas masyarakat, dan lain sebagainya.Belum ada prediksi yang tepat untuk menunjukkan atau mengukur kepadatan vektor(terutama Aedes aegypti di lingkungan kota/kabupaten pada tingkat kecamatan maupun desa. Penyebaran DBD dipengaruhi faktor iklim seperti curah hujan, suhu, dan kelembaban ${ }^{8,9}$. Iklim yang tidak stabil juga menjadi salah satu faktor yang mempengaruhi keberhasilan sistem reproduksi (perkembangbiakan) vektor nyamuk Aedes aegypti betina. Banyaknya faktor yang mempengaruhi Kejadian Demam Berdarah Dengue (DBD) yang bila tanpa penanganan yang tepat akan mengakibatkan kematian. Berbagai upaya pengendalian prevalensi kasus DBD khususnya pada daerah dengan transmisi yang tinggi atau persisten sangat diperlukan. Kasus DBD dipengaruhi oleh jumlah penduduk pada suatu wilayah yang dicerminkan melalui perhitungan Incidence Rate (IR) dari provinsi Bali9.

Pada tahun 2015jumlah penderita DBD dilaporkan sebanyak 10.759 kasus dengan jumlah kematian 29 orang (Incidence Rate/Angka Kesakitan: 259,1 per 100.000 penduduk dan CFR/angka kematian: $0,3 \%$ ), adalah lebih rendah dibandingkan tahun 2016 dengan jumlah penderita DBD yang dilaporkan sebanyak 20.306 kasus dengan jumlah kematian 58 orang (Incidence Rate/Angka Kesakitan: 483 per 100.000 penduduk dan CFR/angka kematian: $0,3 \%$ ). Pada tahun 2017, jumlah penderita DBD yang dilaporkan menurun yaitu sebanyak 4.487 kasus dengan jumlah kematian 16 orang (Incidence Rate/Angka Kesakitan: 105,7 per 100.000 penduduk dan CFR/angka kematian: $0,4 \%$ ). Situasi IR tahun 2017 lebih rendah dibandingkan dengan 4 tahun sebelumnya. IR tertinggi terjadi pada tahun 2016. Target nasional Angka Kesakitan (IR) DBD tahun 2017 yaitu $<49$ per 100.000 penduduk. Sedangkan angka kesakitan DBD di Provinsi Bali tahun 2017 adalah 105,7 per 100.000 penduduk diatas target nasional ${ }^{9,10,11}$. Penelitian ini bertujuan untuk memberikan pemaparan berupa gambaran kejadian DBD di Pulau Bali.

\section{MATERI DAN METODE}

Penelitian ini merupakan penelitian deskriptif dengan rancang bangun case series. Sumberdata pada penelitian ini menggunakan data sekunder yaitu Profil Kesehatan provinsi Bali tahun 2015 hingga 2017, dan data tahun 2015-2017yang diperoleh dari Badan Pusat Statistik provinsi Bali.

Penelitian ini menggambarkan kejadian DBD dengan pendekatan kasus epidemiologi lingkungan menurut tempat (Kabupaten/kota, mobilitas, dan waktu. Variabel yang diteliti dalam penelitian ini adalah jumlah penduduk, geografi, iklim, dan kejadian DBD di Pulau Bali.

\section{HASIL DAN PEMBAHASAN}

Provinsi Bali dengan 9 kabupaten /kota terdiri dari Pulau Bali sebagai pulau terbesar dan pulau kecilkecil di sekitarnya, yaitu Pulau Nusa Penida, Pulau Nusa Ceningan, Pulau Nusa Lembongan, dan Pulau Serangan yang terletak di sekitar kaki Pulau Bali, serta Pulau Menjangan yang terletak di bagian barat. Provinsi Bali merupakan salah satu dari 34 provinsi di 
Indonesia terletak antara pulau Jawa dan Pulau Lombok. Secara geografi provinsi Pulau Bali adalah daerah tropis dengan titik koordinat $08^{\circ} 03^{\prime} 40^{\prime \prime}$ $08^{\circ} 50^{\prime} 48^{\prime \prime}$ Lintang Selatan dan $114^{\circ} 25^{\prime} 53^{\prime \prime}-115^{\circ} 42^{\prime} 40^{\prime \prime}$ Bujur Timur.

Secara umum Pulau Bali memiliki iklim laut tropis yang dipengaruhi oleh angin musiman. Pulau Bali memiliki musim kemarau dan musim hujan yang diselingi oleh musim pancaroba ${ }^{9,10,11}$. Rata-rata suhu di Bali sekitar $23,2^{\circ} \mathrm{C}-32,7^{\circ} \mathrm{C}$ dengan rerata kelembaban udara 63- $90 \%$. Curah hujan rata-rata setiap tahun berkisar antara 1.428,5 s/d 1.796,6 mm dan curah hujan tertinggi terjadi pada bulan Nopember, Desember, Januari, dan Pebruari, sedangkan curah hujan terendah terjadi di bulan Juni, Agustus, September, dan Oktober. ${ }^{14}$ Kepadatan penduduk di kota /kabupaten Pulau Bali selalu mengalami kenaikan setiap tahunnya. ${ }^{11,12,13}$

\section{Peta Propinsi Bali}

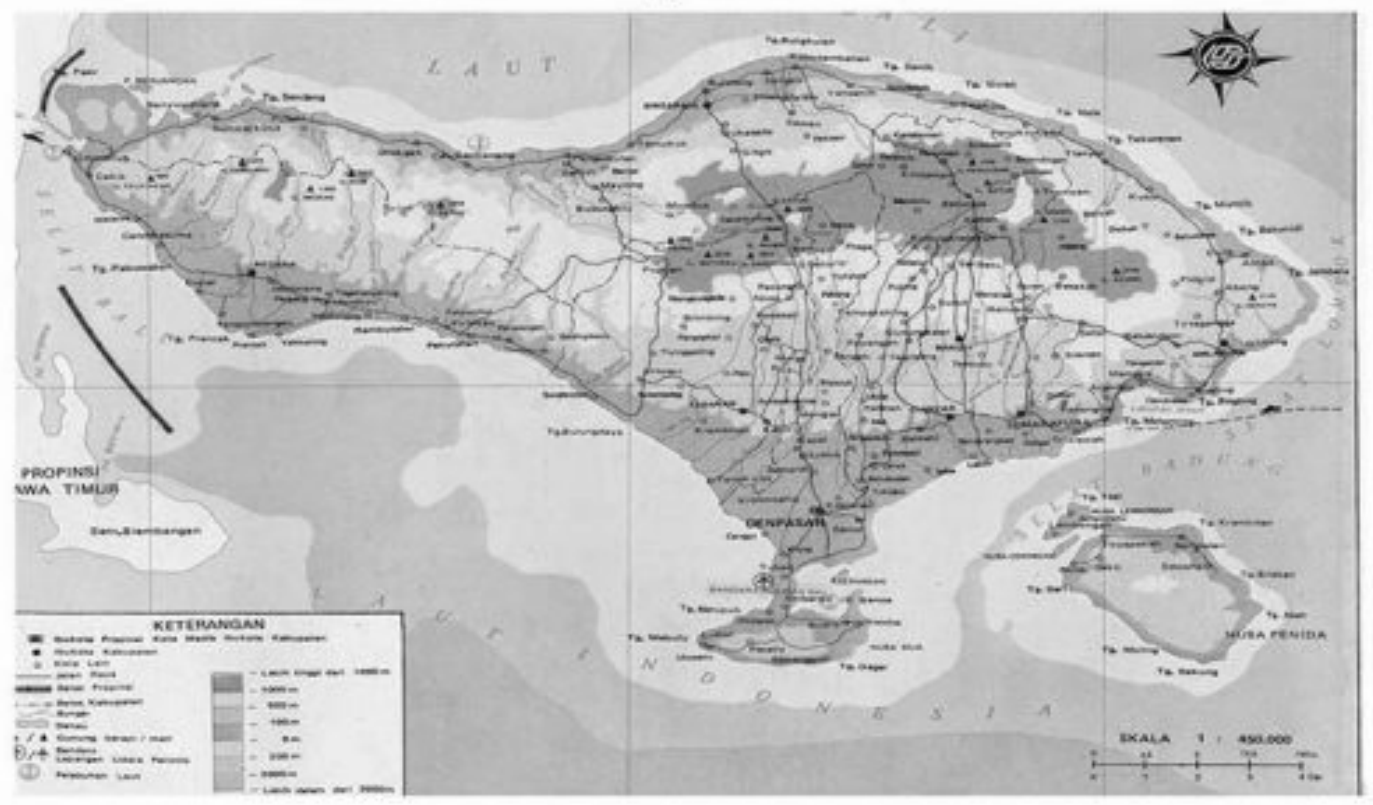

Gambar 1. Geografi daerah penelitian

GEOGRAFI Pulau Bali dengan 9 kabupaten/kota.

Sumber: profil kesehatan Provinsi Bali, 2018.

Tabel 1. Letak Geografis Pulau Bali dan 9 kota/ Kabupaten di Provinsi Bali, 2017

\begin{tabular}{|c|c|c|c|}
\hline No. & Kabupaten & Lintang Selatan & Bujur Timur \\
\hline 1. & Jembrana & $8^{\circ} 03^{\prime} 40^{\prime \prime}-8^{\circ} 60^{\prime} 48^{\prime \prime}$ & $114^{\circ} 25^{\prime} 53^{\prime \prime}-115^{\circ} 42^{\prime} 40^{\prime \prime}$ \\
\hline 2. & Tabanan & $8^{\circ} 14^{\prime} 30^{\prime \prime}-8^{\circ} 30^{\prime} 07$ " & $114^{\circ} 54^{\prime} 52^{\prime \prime}-115^{\circ} 12^{\prime} 57^{\prime \prime}$ \\
\hline 3. & Badung & $8^{\circ} 14^{\prime} 20^{\prime \prime}-8^{\circ} 50^{\prime} 48^{\prime \prime}$ & $115^{\circ} 05^{\prime} 00^{\prime \prime}-115^{\circ} 26^{\prime} 16^{\prime \prime}$ \\
\hline 4. & Gianyar & $8^{\circ} 18^{\prime} 48^{\prime \prime}-8^{\circ} 38^{\prime} 58^{\prime \prime}$ & $115^{\circ} 05^{\prime} 29^{\prime \prime}-115^{\circ} 22^{\prime} 23^{\prime \prime}$ \\
\hline 5. & Klungkung & $8^{\circ} 27^{\prime} 37^{\prime \prime}-8^{\circ} 49^{\prime} 00$ " & $115^{\circ} 21^{\prime} 28^{\prime \prime}-115^{\circ} 37^{\prime} 43^{\prime \prime}$ \\
\hline 6. & Bangli & $8^{\circ} 08^{\prime} 30^{\prime \prime}-8^{\circ} 31^{\prime} 27^{\prime \prime}$ & $115^{\circ} 13^{\prime} 48^{\prime \prime}-115^{\circ} 27^{\prime} 24^{\prime \prime}$ \\
\hline 7. & Karangasem & $8^{\circ} 10^{\prime} 00^{\prime \prime}-8^{\circ} 33^{\prime \prime} 00 "$ & $115^{\circ} 23^{\prime} 28^{\prime \prime}-115^{\circ} 42^{\prime} 40^{\prime \prime}$ \\
\hline 8 & Buleleng & $8^{\circ} 03^{\prime} 40^{\prime \prime}-8^{\circ} 23^{\prime} 00^{\prime \prime}$ & $114^{\circ} 25^{\prime} 55^{\prime \prime}-115^{\circ} 27^{\prime} 28^{\prime \prime}$ \\
\hline 9 & Denpasar & $8^{\circ} 35^{\prime} 31^{\prime \prime}-8^{\circ} 44^{\prime} 49^{\prime \prime}$ & $115^{\circ} 10^{\prime} 23^{\prime \prime}-115^{\circ} 16^{\prime} 27^{\prime \prime}$ \\
\hline
\end{tabular}


Tabel 2. Jumlah Penduduk, Luas Wilayah, dan Kepadatan Penduduk Di Prov Bali tahun 2012-2017

\begin{tabular}{cccccr}
\hline Tahun & $\begin{array}{c}\text { Luas } \\
\left(\mathbf{K m}^{\mathbf{2}} \mathbf{)}\right.\end{array}$ & $\begin{array}{c}\text { Penduduk } \\
\text { laki laki }\end{array}$ & $\begin{array}{c}\text { Penduduk } \\
\text { perempuan }\end{array}$ & Jumlah & $\begin{array}{c}\text { Kepadatan } \\
\mathbf{J i w a} / \mathbf{K m}^{\mathbf{2}}\end{array}$ \\
\hline 2012 & 5636,66 & 209.484 & 203.833 & 4.137 .814 & 734 \\
2013 & 5636,66 & 204.200 & 201.430 & 4.056 .300 & 729 \\
2014 & 5636,66 & 206.670 & 203.820 & 4.104 .900 & 728 \\
2015 & 5636,66 & 209.100 & 206.180 & 4.152 .800 & 736,75 \\
2016 & 5636,66 & 211.500 & 208.510 & 4.200 .100 & 745,14 \\
2017 & 5636,66 & 213.840 & 210.810 & 4.246 .500 & 753,37 \\
\hline
\end{tabular}

Sumber: BPS Bali 2018

Kepadatan penduduk di Provinsi Bali sejak tahun 2012 hingga tahun 2017 mengalami peningkatan setiap tahunnya kecuali pada tahun 2012. Hingga tahun 2017 jumlah penduduk di Provinsi Bali berdasarkan Badan Pusat Statistika (BPS) adalah 4.246.500 dengan kepadatan pendduduk 753,37 Jiwa $/ \mathrm{Km}^{2}$. Pulau Bali terbagi menjadi 9 kabupaten/kota, 57 kecamatan, dan 176 desa/kelurahan. Tahun 2017 Penduduk pulau Bali mencapai 4.246.500 jiwa dengan luas area 5636, 7 $\mathrm{Km}^{2}$.
Pada tahun 2017 jumlah kasus terbanyak adalah di Kabupaten Badung yaitu 941 kasus, Kota Denpasar sebanyak 929 kasus, Kabupaten Buleleng sebanyak 890 kasus, dan Kabupaten Gianyar sebanyak 511 kasus. Daerah-daerah tersebut memiliki jumlah penduduk yang besar dengan tingkat kepadatan penduduk yang tinggi sehingga merupakan salah satu faktor resiko penyebaran Demam Berdarah Dengue (DBD).

Tabel 3. Luas Wilayah Jumlah Desa/Kelurahan, Jumlah Penduduk, Kepadatan Penduduk per km². Di Pulau Bali 2017

\begin{tabular}{llrrrrrr}
\hline No & Kab/Kota & $\begin{array}{c}\text { Luas Wilayah } \\
\left(\mathrm{km}^{2}\right)\end{array}$ & Desa & Kelurahan & $\begin{array}{c}\text { Desa }+ \\
\text { Kelurahan }\end{array}$ & $\begin{array}{c}\text { Jumlah } \\
\text { Penduduk }\end{array}$ & $\begin{array}{c}\text { Kepadatan Penduduk } \\
\text { per km }{ }^{2}\end{array}$ \\
\hline 1. & Tabanan & 839,33 & 133 & 0 & 133 & 441.000 & 525,42 \\
2. & Denpasar & 127,78 & 27 & 16 & 43 & 914.300 & 7155,27 \\
3. & Klungkung & 315,00 & 53 & 6 & 59 & 177.400 & 563,17 \\
4. & Karangasem & 839,54 & 75 & 3 & 78 & 412.800 & 491,70 \\
5. & Jembrana & 841,80 & 41 & 10 & 51 & 274.900 & 326,56 \\
6. & Gianyar & 468,00 & 64 & 6 & 70 & 503.900 & 1537,56 \\
7. & Buleleng & 1365,88 & 129 & 19 & 148 & 653.600 & 472,58 \\
8. & Bangli & 520,81 & 68 & 4 & 72 & 255.100 & 432,21 \\
9. & Badung & 418,52 & 46 & 16 & 62 & 643.500 & 1537,56 \\
\hline & TOTAL & 5636,70 & 636 & 80 & 716 & 4.246 .500 & 753 \\
\hline
\end{tabular}

Sumber : BPS Bali, 2018

Kota Denpasar pada tahun 2017 penduduknya berjumlah 914.279 jiwa dan merupakan, kota terbanyak penduduknya di Pulau Bali dengan perkembangan fasilitas baru dalambidang pariwisata.
Kepadatan penduduk didapatkan dari jumlah penduduk di bagi denganluas wilayah. Semakin besar jumlah penduduk Bali maka kepadatan penduduk juga meningkat.

Tabel4. Gambaran Incidence Rate /IR dan Case Fatality Rate /CFR DBD di Provinsi/Pulau Bali tahun 20122017.

\begin{tabular}{lcccccc}
\hline (Incidence Rate/Case Fatality Rate) & Tahun & Tahun & Tahun & Tahun & Tahun & Tahun \\
& 2012 & 2013 & 2014 & 2015 & 2016 & 2017 \\
\hline Incidence Rate(IR) & 65.55 & 174.5 & 210.2 & 259.1 & 483 & 105.7 \\
Case Fatality & 0.3 & 0.11 & 0.2 & 0.3 & 0.3 & 0.4 \\
Rate (CFR) & & & & & & \\
\hline
\end{tabular}

Sumber: Profil Dinas Kesehatan Provinsi Bali 2012-2017. 


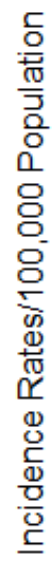

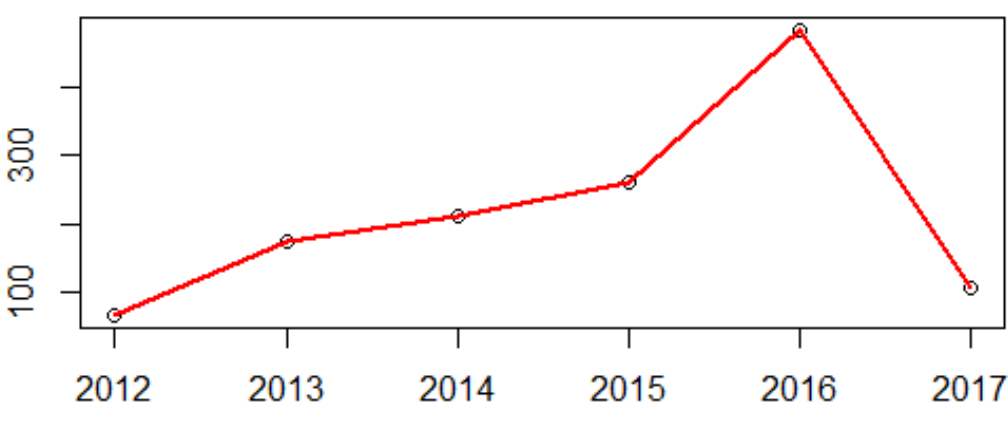

Tahun

Gambar 2 Incidence Rates (IR) di Provinsi Bali tahun 2012 - 2017

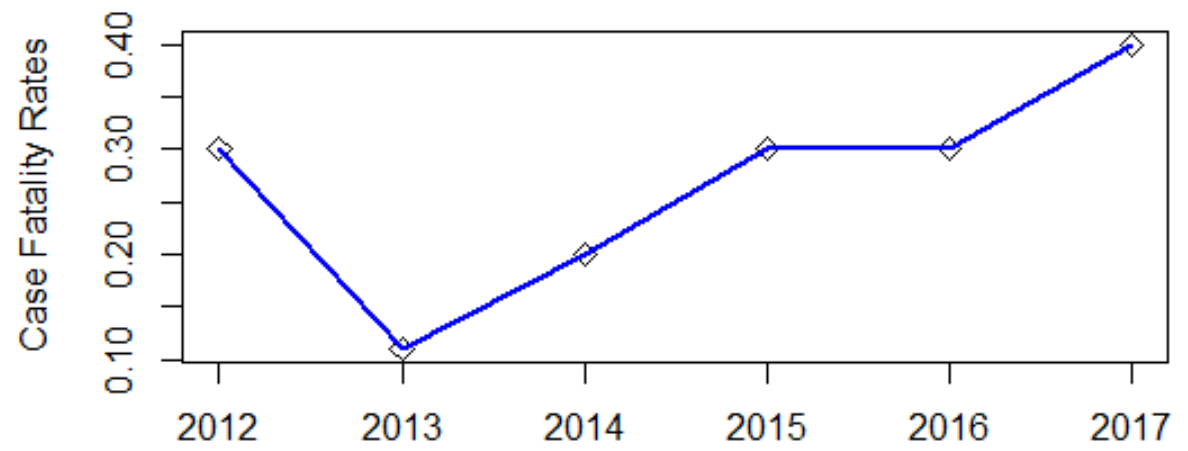

Tahun

Gambar 3 Case Fatality Rates (IR) di Provinsi Bali tahun 2012 - 2017

Incidence Rate (IR) DBD di Provinsi Bali tahun 2017 sebesar 105,7/100.000penduduk dengan CFR (case fatality rate) sebesar $0,4 \%$ naikjika dibandingkan tahun 2016. Jika dibandingkan dengan target Renstra Dinas Kesehatan tahun 2013-2018 sebesar $<1 \%$, CFR tahun 2017 sudah memenuhi target.

DemamBerdarah Dengue merupakan penyakit infeksi virus akut yang disebabkan oleh virus dengue yang tergolong Arthropod-Borne virus, genus flavivirus, family flaviviridae. DBD ditularkan melalui gigitan nyamuk Aedes spp, Aedes aegypti, dan Aedes albopictus merupakan vektor utama penyakit DBD.Penyakit DBD dapat munculsepanjang tahun dan dapat menyerang seluruh kelompok umur. Penyakit ini berkaitandengan kondisi lingkungan dan perilaku masyarakat. Hingga tahun 2017 DBD merupakan penyakit 10 terbesar di Provinsi Bali, dan berdasarkan data sekunder Ditjen Pencegahan dan Pengendalian Penyakit Kemenkes (2018) melaporkan, bahwa pada tahun 2011-2015 kecuali tahun 2012 ProvinsiBali menduduki peringkat pertama dalam kejadian DBD diIndonesia. Sehingga untukmenurunkanangka insidentersebutperludiketahui penyebab peningkatan kejadian tersebut.

Tabel 5. Distribusi jumlah kasus dan kematian karena DBD di kabupaten/kota pulau Bali tahun 2017

\begin{tabular}{clrr}
\hline No. & Kabupaten/kota & $\begin{array}{c}\text { Jumlah } \\
\text { kasus }\end{array}$ & $\begin{array}{c}\text { Jumlah } \\
\text { Kematian }\end{array}$ \\
\hline 1 & Badung & 941 & 6 \\
2 & Denpasar & 929 & 4 \\
3 & Buleleng & 890 & 3 \\
4 & Gianyar & 511 & 2 \\
5 & Bangli & 320 & 0 \\
6 & Tabanan & 316 & 0 \\
7 & Karangasem & 221 & 0 \\
8 & Klungkung & 219 & 1 \\
\hline & Total & 4347 & 16 \\
\hline
\end{tabular}

Sumber: Profil Dinas Kesehatan Provinsi Bali 2018 


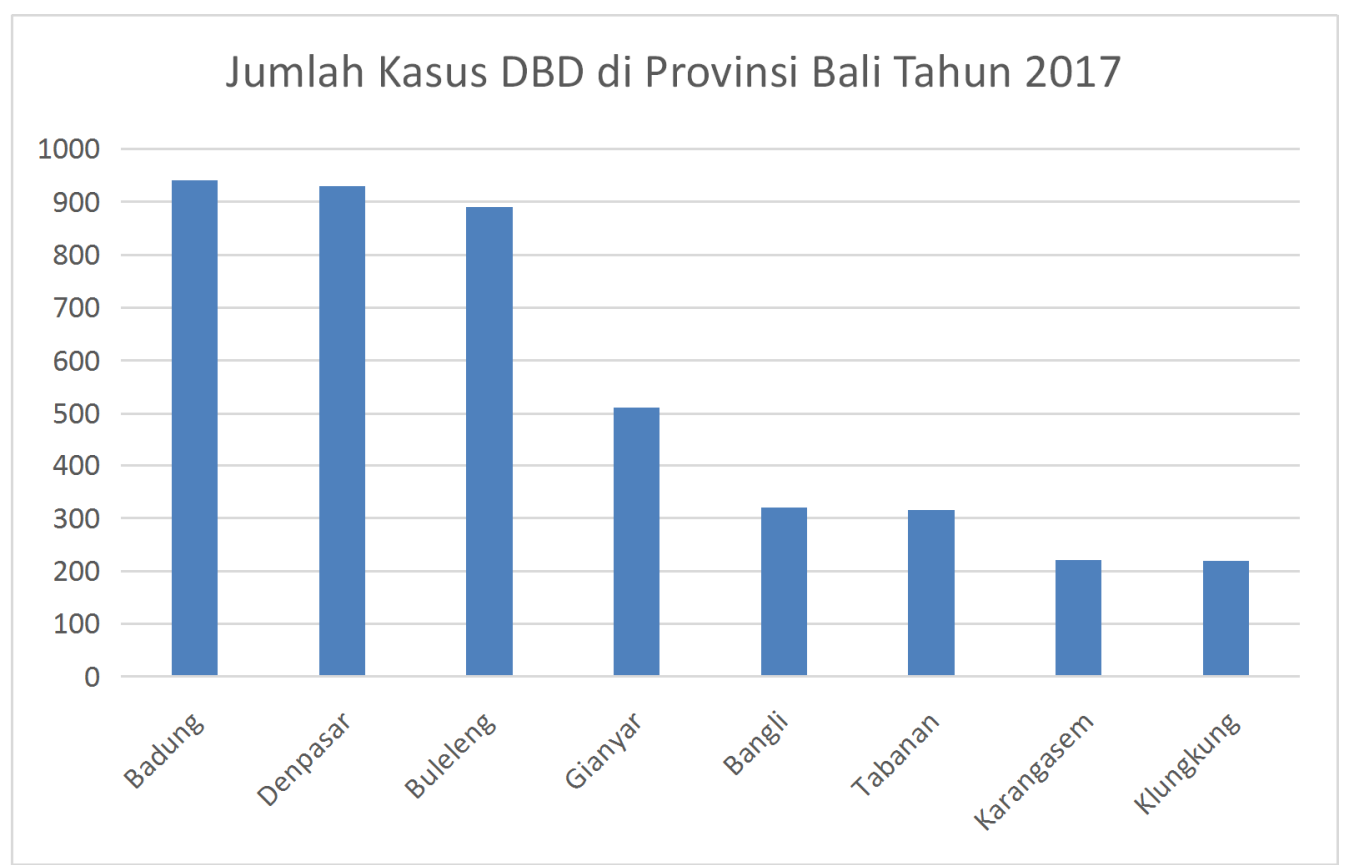

Gambar 4 Jumlah kasus DBD per Kabupaten di Provinsi Bali Tahun 2017

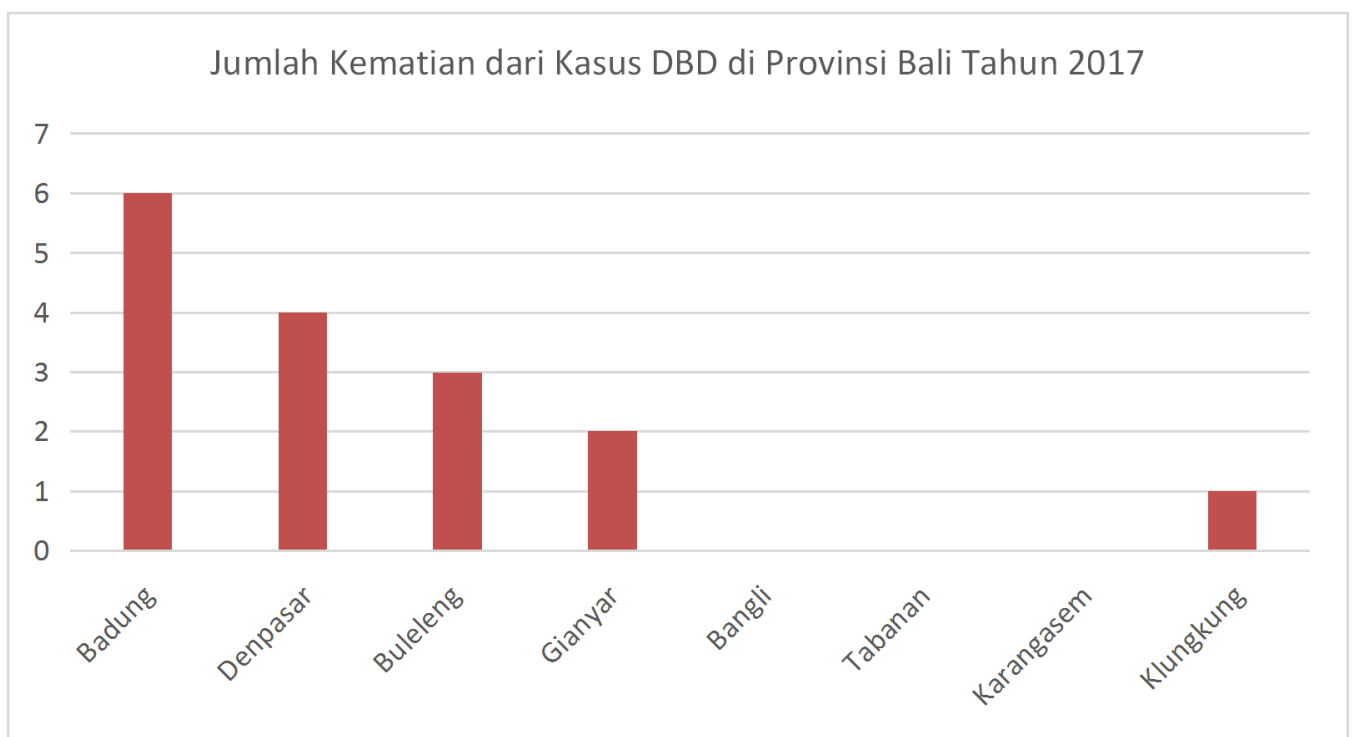

Gambar 4: Jumlah kematian dari kasus DBD per Kabupaten di Provinsi Bali Tahun 2017

Berdasarkan Tabel 5, dapat dilihat jumlah kematian tertinggi pada tahun 2017 terdapat di Kabupaten Badung yaitu 6 orang, Kota Denpasar sebanyak 4orang, Buleleng 3 orang, Gianyar2 orang, dan Klungkung 1 orang sehingga total kasus kematian karena DBD di Provinsi Bali sebanyak 16 kasus. Kasus kematian DBD terjadi di kabupaten/kota yang jumlah kasus DBDnya tinggi, Kabupaten Badung adalah salah satu kabupaten yang ada di Bali yang termasuk dalam kategori endemis dalam tingkat desa ataupun kecamatan. Berdasarkan data yang ada, distribusi Demam berdarah dengue (DBD) di kelurahan endemis terletak di wilayah kecamatan Kuta Utara dan Kuta.
Kejadian DBD meningkat saat musim hujan pada bulan Februari, Mei, dan Juni. Kecamatan Kuta daerah pariwisata menjadi tempat destinasi wisata para wisatawan baik lokal maupun mancanegara ${ }^{13,14}$. Selain itu dengan adanya mobilitas masyarakat penduduk baik wisatawan ataupun pekerja memungkinkan terbawanya agen virus dengue melalui nyamuk Aedes aegypti dalam media yang terikut transportasi. Mobilitas masyarakat dapat meningkatkan penyebarluasan habitat nyamuk terutama nyamuk Aedes aegypti yang bersifat anthropilik (suka dekat dengan manusia). Musim hujan dengan curah hujan yang tinggi mengakibatkan banyak genangan air di sekitar perumahan dan pemukiman masyarakat sehingga di gunakan sebagai 
tempat perindukan (breeding place) nyamuk Aedes aegyptiyang berdampak meningkatnya populasi nyamuk tersebut dan akan berpengaruh terhadap peningkatan penularan DBD di masyarakat.

Migrasi atau mobilitas lokal terjadi diantara Kota Denpasar dan Kabupaten Badung maupun Gianyar selama tahun 2015-2016, hal ini karena adanya faktorsocial ekonomidimana kota Denpasar adalah ibukota provinsi Bali merupakan tempat perkantoran, perdagangan maupun bisnis, ${ }^{14}$ sementara masyarakat banyak bertempat tinggal di Kabupaten Badung. Mobilitas pada lingkungan lokal dimana jarak antar kabupaten/kota relatif dekat memungkinkan masyarakat sering bepergian dengan mudah. Mobilitas seperti ini dapat meningkatkan penyebaran DBD dari satu masyarakat di daerah endemis ke daerah non endemis DBD dalam satu Pulau, seperti di Pulau Bali.

Secara topografi daerah yang datar di dataran rendah seperti pantai, sawah, tambak/kolam merupakan daerah wisata yang di sukai wisatawan maupun nyamuk terutama Aedes aegypti yang bersifat anthropophilic yang berarti lebih menyukai menghisap darah manusia daripada hewan. Secara kependudukan $50 \%$ masyarakat Bali dari total populasi penduduk bertempat tinggal di bagian selatan Pulau Bali ${ }^{14,15,16}$. Kunjungan wisatawan dari berbagai tempat berpotensi meningkatkan maupun menyebarkan DBD. Pada Tahun 2011 ditemukan adanya kesamaan serotipe virus Dengue antara penduduk lokal dan wisatawan di Bali ${ }^{14,15}$, dari beberapa penelitian virus dengue dibawa oleh wisatawan, sehingga pentingnya Bali dalam kaitannya dengan Kejadian Luar Biasa (KLB) DBD ${ }^{15,17,18}$.

Wilayah Bali bagian selatan merupakan daerah yang berkembang pesat dalam pembangunan infrastruktur dan pertambahan penduduknya. Selain itu dikenal paling populer di kalangan wisatawan karena terkenal dengan areanya seperti Kuta, Legian, Seminyak, daerah tenang Canggu, Sanur, Nusa Dua, serta Bukit Peninsula.Bagian selatan juga merupakan lokasi bandara Ngurah Rai.Sementara Kabupaten Gianyar memiliki salah satu tempat endemis DBD yaitu Kecamatan Ubud yang menempati jumlah kasus terbanyak. Kecamatan Ubud merupakan destinasi pariwisata di Kabupaten Gianyar.

Kebanyakan masyarakat bertempat tinggal di kabupaten Gianyar dan Badung bermobilitas tinggi ke kota Denpasar dan sebaliknya. Di Gianyar proporsi DBD dengan mobilitas $66 \%$ lebih tinggi dibanding yang tanpa mobilitas (33\%). Secara geografi kabupaten Gianyar dekat dengan daerah endemis DBD seperti wilayah Kuta(kabupaten Badung) dan Kota Denpasar ${ }^{17,19}$.

Pada musim kemarau di $\mathrm{p}$ Bali terjadi penurunan hari hujan maupun curah hujan, sumber sumber air mengering sehingga terjadi kelangkaan air. ${ }^{18}$ Kondisi ini berpengaruh terhadap masyarakat lokal yang menggantungkan penyediaan air bersih dari sumber sumber air; seperti sumur bor, air hujan, air permukaan seperti kolam, sungai, kali maupun sumur. ${ }^{17,19,20}$

Bertambahnya industri pariwisata juga meningkatkan kebutuhan air bersih untuk memenuhi kebutuhan para wisatawan, terutama di daerah pariwisata seperti di Kabupaten Badung dan Kabupaten Gianyar.

Keterbatasan air membuat masyarakat menyimpan air dalam wadah/kontainer yang mana bisa jadi tempat perindukan nyamuk ${ }^{21,22}$.

Pertumbuhan ekonomi dan pariwisata membuat lahan sawah berubah menjadi lingkungan perumahan dan pemukiman dengan cepat, sehingga menambah habitat nyamuk Aedes spp bertambah. Meningkatnya kontak antara vektor dan masyarakat, iklim, serta kelangkaan air telah menjadi masalah di Pulau Bali $^{22,23,24,25}$.

\section{SIMPULAN}

Insiden Demam Berdarah Dengue (DBD) di Pulau Bali mengikuti pola musiman, sebagian besar kejadian DBD pada Januari hingga Mei, cuaca lokal, kondisi sosial ekonomi masyarakat, curah hujan, topografi,dan mobilitas penduduk mempengaruhi kejadian DBD di beberapa kabupaten/kota di pulau Bali.

Insiden DBD di Provinsi Bali tahun 2017 sebesar 105,7/100.000 penduduk dengan CFR (case fatality rate) sebesar 0,4\% naik dibandingkan tahun 2016 0,3\%. Kabupaten Badung menduduki tingkat tertinggi kejadian DBD dengan 941 kasus 6 diantaranya meninggal. Insisiden DBD terjadi pada bulan Januari, Februari, Maret, April dan Mei.

Disarankan pada Pemerintah daerah provinsi Bali agar mengutamakan daerah di kelurahan/desa yang diidentifikasi berisiko tinggi DBD, perlu dilakukan pengendalian, pemantauan, serta prediksi yang baik terjadinya penularan Demam Berdarah Dengue (DBD) terutama di daerah pariwisata yang banyak dikunjungi wisatawan domestik maupun mancanegara. Pemerintah daerah Provinsi Bali dalam hal ini Dinas kesehatan perlu untuk merekomendasikan kepada para wisatawan agar menggunakan tindakan perlindungan pribadi seperti membawa anti nyamuk, menggunakan pakaian yang terlindung dari gigitan nyamuk selama di Pulau Bali, terutama selama periode puncak endemis DBD. Sementara penduduk disarankan untuk melaksanakan program 3M dan PSN terutama di daerah tujuan wisata.

\section{UCAPAN TERIMA KASIH}

Ucapan terima kasih kami sampaikan kepada DRPM Kemenristekdikti RI melalui Lembaga Penelitian dan Inovasi Universitas Airlangga, sebagai pemberi dana kegiatan penelitian ini dengan nomor kontrak no 755/UN.3.14/LT/2019:

\section{DAFTAR PUSTAKA}

1. AjiR, Kamaluddin MT, Salni\&Sriati.
Environmental factors and indices related 
todengue vectorlarva in Rejang Lebong District. International Research JournalofPublicandEnvironmentalHealth, 2016; 3(7): $162-166$.

2. Bhat S, Gething PW, Brady OJ, Messina JP, Farlow AW, Moyes CL, et al. The Global distribution and burder of dengue. Nature 2013; 496(7446):504-7

3. Kraemer MU, Sinka ME, Duda KA, Mylne AQ, Shearer FM, Barker CM, et al. The Global distribution of the arbovirus Aedes aegypti dan Ae. albopictus. Elife; 2015: 4:e08347, https://doi.org/10.7554/eLife.08347.

4. Kementerian Kesehatan Republik Indonesia. Profil Kesehatan Indonesia tahun 2017. Kemenkes RI.2018.

5. Tian H, Sun Z, Faria NR, Yang J, Cazelles B, Huang $S$, et al. Increasing airlane travel may facilitate Co-circulation of multiple dengue virus serotypes in Asia. PloS Negleted Trop. Dis; 2017: 11(8). eb0005694 https://doi.org/10.1371/journal.pntd.

6. Kementerian Kesehatan republik Indonesia. Infodatin : situasi DBD di Indonesia tahun 2016.Kemenkes RI. 2016.

7. Wowor R. Pengaruh kesehatan lingkungan terhadap perubahan epidemiologi Demam Berdarah Dengue di Indonesia. Jurnal E-Clinic (eCl); 2017: 5(2), 105-113.

8. DhewantaraPW, MarinaR, Puspita T, Ariati Y, PurwantoE, Hananto M, Soares Magalhaes RJ. Spatial and temporal variation of dengue incidence in the island of Bali, Indonesia: An ecological study. Travel Medicine and Infectious Disease;23(201932). https://doi.org/10.1016/J.TMAID.2019.06.00810

9. Qi, X., Wang, Y., Li, Y., Meng, Y., Chen, Q., Ma, J., \& Gao, G. F.The Effects of Socioeconomic and Environmental Factors on the Incidence of Dengue Fever in the Pearl River Delta, China, 2015. PLoS Neglected Tropical Diseases. https://doi.org/10.1371/journal.pntd.0004159

10. World Health Organization. Global Strategy for dengue prevention and control 2012-2020, Geneva, WHO.press. 2012

11. Ernst T, McCarthy S, Chidlow G, Luang-Suarkia D, Holmes EC, Smith DW, Imrie A. Emergence of a New Lineage of Dengue Virus Type 2 Identified in Travelers Entering Western Australia from Indonesia, 2010-2012. PLoS Neglected Tropical Disease; 2015, https://doi.org/10.1371/journal.pntd.0003442

12. Sohail A, McGuinness SL, Lightowler R, Leder K, Jomon B, Bain CA, Peleg AY. Spectrum of illness among returned Australian travellers from Bali, Indonesia: a 5-year retrospective observational study. Internal Medicine Journal; 2019, 48(1):34-40 https://doi.org/10.1111/imj.13993

13. Yoshikawa MJ, Kusriastuti R. Surge of dengue virus infection and chikungunya fever in Bali in 2010: The burden of mosquito-borne infectious diseases in a tourist destination. Tropical Medicine and Health; 2013, 41(2):67-78. doi: 10.2149/tmh.2011-05Biro Statistik Prov Bali. 2016. Denpasar, 2016.

14. PalaniyandiM. The role of remote sensing and GIS for spatial prediction of vector-borne diseases transmission: A systematic review. Journal of Vector Borne Diseases. 2012: 49: 197-204

15. Wijayanti, SPM, PorphyreT, Chase-Topping M, RaineySM, McFarlane M, Schnettler E, Kohl A. The Importance of Socio-Economic Versus Environmental Risk Factors for Reported Dengue Cases in Java, Indonesia. PLoS Neglected Tropical Diseases. 2016, https://doi.org/10.1371/journal.pntd.0004964

16. Vannavong N, Seidu R, Stenström TA, Dada N, Overgaard HJ. Effects of socio-demographic characteristics and household water management on Aedes aegypti production in suburban and rural villages in Laos and Thailand. Parasites Vectors. 2017 : $10(1)$ : 170 https://doi.org/10.1186/s13071-017-2107-7

17. Kesetyaningsih TW, Andarini S, Sudarto, Pramoedyo H. Determination of environmental factors affecting dengue incidence in Sleman District, Yogyakarta, Indonesia. African Journal of Infectious Diseases. 2018: 12(S):13-25. https://doi.org/10.2101/Ajid.12v1S.3

18. HusninaZ, Clements ACA, Wangdi K.Forest cover and climate as potential drivers for dengue fever in Sumatra and Kalimantan 2006-2016: a spatiotemporal analysis. Tropical Medicine and International Health. 2019: 24(7): 888-898. https://doi.org/10.1111/tmi.13248

19. Kemenkes RI, Infodatin Situasi DBD di Indonesia 2017. Kemenkes RI Jakarta. 2018.

20. Dinas Kesehatan Provinsi Bali, Profil Kesehatan Provinsi Bali 2017. Denpasar. 2018.

21. Cleveland RB, Cleveland WS, McRae JE, Terpenning I. STL: A Seasonal-Trend Composition. J Off Stat 1990;6(1):3-73.

22. Azhar K, Marina R, Anwar A. A prediction model of dengue incidence using climate variability in Denpasar city. Health science J Indonesia.2017: 8(2): 68-73.

23. Pranata S, fauziah Y. Budisuari MA, Kusrini.I. Riskesdas dalam angka Provinsi Bali. 2018.

24. Wijayanti SP, Sunaryo S, Suprihatin S, MC Farlane M, Rainey SM, Dietrich I et al. Dengue in Java, Indonesia: relevance of Mosquito indices as risk predictors. PloS Negleted Trop Dis 2016: 10(3) $\quad$ e 0004500. https://doi.org/10.1371/journal.pntd00045000. 